\title{
Impact of Adolescents' Sleeping Problems and Habits on the Quality of Their Sleep
}

\section{Adölesanların Uyku Problemlerinin ve Alıșkanlıklarının Uyku Kalitesine Etkisi}

\author{
(1) Nihal Gamze Tetik, (1) Gülcan Kar Şen* \\ Ministry of Health Yenice District State Hospital, Specialized Nurse, Karabük, Turkey \\ *Karabük University Faculty of Health Sciences, Department of Nursing, Karabük, Turkey
}

\begin{abstract}
Objective: This study aimed to determine the impact of adolescents' sleeping problems and habits on the quality of their sleep.

Materials and Methods: The Pittsburgh Sleep Quality index (PSQI) was administered to a group of 820 high school students in Turkey. A computerised assessment was made of the data obtained.

Results: The mean age of the participating adolescents was $16 \pm 1.14$ years, $50.37 \%$ of whom had poor sleep quality. Statistically significant differences $(p<0.05)$ were noted in their overall PSQI scores in terms of their use of alcohol/cigarettes $(p=0.001)$, surfing the internet $(p=0.000)$, watching TV $(p=0.026)$ and eating something before going to bed $(p=0.003)$. Based on the regression analysis, as the difficulty in falling asleep increases, the PSQI score is 2.5 times; as the state of waking up by jumping increases, the PSQI score is 1.6 times and as the smoking status increases, the PSQI score is 1.6 times.

Conclusion: More than half of the participating adolescents had poor sleep quality. Sleep-related problems present serious risks in terms of adolescents' physical and emotional health, academic achievement and safety. Because of this, factors that may disturb adolescents' sleep patterns must be kept to a minimum, and school health teams need to promote healthy sleep habits among adolescents.
\end{abstract}

Keywords: Adolescent, sleep quality, school health, nursing
Öz

Amaç: Bu çalışmada adölesan dönemdeki uyku problemlerinin ve alışkanlıklarının uyku kalitesine etkisini belirlemek amaçlanmıştır.

Gereç ve Yöntem: Türkiye'de öğrenim gören 820 lise öğrencisine, Pittsburgh Uyku Kalitesi indeksi (PUKI) uygulandı. Elde edilen veriler bilgisayar ortamında değerlendirildi.

Bulgular: Araştırmaya katılan adölesanların yaş ortalaması $16 \pm 1,14$ yıl olup, \%50,37'si kötü uyku kalitesine sahipti. Alkol/sigara kullanımı $(p=0,001)$, internette gezinme $(p=0,000)$, TV seyretme $(p=0,026)$, yatmadan önce yiyecek tüketme $(p=0,003)$ ile PUKI toplam puan arasında istatistiksel olarak anlamlı fark vardı $(p<0,05)$. Regresyon analizinde uykuya dalmakta zorlanma durumu arttıkça PUKI puanı 2,5 kat, uykuda sıçrayarak uyanma ve sigara kullanma durumu arttıkça PUKI puanı 1,6 kat arttı.

Sonuç: Çalışmaya katılan adölesanların yarıdan fazlasının uyku kalitesi düşüktür. Adölesanın uyku ile ilgili problemleri onların fiziksel ve duygusal sağlığı, akademik başarısı ve güvenliği için ciddi bir risk oluşturmaktadır. Bu nedenle adölesanların uyku rahatlığını etkileyecek faktörlerin en aza indirilmesi ve adölesan uyku sağlığının okul sağlığı ekiplerince geliştirilmesi gerekmektedir.

Anahtar Kelimeler: Adölesan, uyku kalitesi, okul sağlığı, hemşirelik

\section{Introduction}

The World Health Organization (WHO) defines adolescence as the period of life corresponding to the ages of 10-19. An individual in adolescent is in a period of rapid biological, psychological, mental and social change. These changes have a major impact on sleep and wakefulness cycles. Sleep is an essential element of a healthy life and has a significant effect on an individual's quality of life and wellbeing. Individual factors and environmental changes have an important impact on sleep patterns. Particularly in the case of adolescents, sleep affects an individual's thinking, behavior and emotional capacities and poor sleep patterns have a negative impact on health. Adolescents must get an adequate amount of sleep and rest if the adverse effects of sleep problems are to be prevented. Studies have indicated that adolescents need an average of 8-10 hours of sleep a day (1). It is seen however that adolescents sleep less than is required and that they experience problems with sleep (2). In adolescence, these sleep problems are especially responsible for attention deficit, memory disorders, diminished learning skills and school performance, issues with motor skills, the risk of weight gain and other difficulties $(1,2)$. Sleep health is usually a matter that is ignored and thus represents a serious

Address for Correspondence/Yazışma Adresi: Nrs. Nihal Gamze Tetik, Ministry of Health Yenice District State Hospital, Specialized Nurse, Karabük, Turkey Phone: +90 5433897852 E-mail: demgamze@hotmail.com ORCID-ID: orcid.org/0000-0001-6123-8897 Received/Geliş Tarihi: 27.12.2019 Accepted/Kabul Tarihi: 21.02.2021

${ }^{\circ}$ Copyright 2021 by Turkish Sleep Medicine Society / Journal of Turkish Sleep Medicine published by Galenos Publishing House. 
threat to public health. Loss of sleep in adolescence is not an indication of a reduced need for sleep in this period but of a combination of biological, psychological and sociocultural influences. Sleep is a state that affects adolescents health, learning, school performance, quality of life and the family as a whole. The American Academy of Pediatrics regards inadequate sleep in adolescence a public health issue that has an adverse effect on students health, safety and academic performance (3). The aim of this study was to identify adolescents sleeping habits and the wide range of variables that impact their quality of sleep in an effort to contribute to the protection, maintenance and improvement of adolescent health.

\section{Materials and Methods}

\section{Participants}

The study universe consisted of 13 high schools operating under the Directorate of National Education in the town of Safranbolu in the province of Karabük, Turkey. A total of 3.259 students were enrolled at these schools. In selecting the sample group, different types of schools/programs were chosen (teaching, religion-affiliated, fine arts, health and vocational/ technical). The students were selected from 5 different high schools that had approximately the same size of enrollment. All of the students in these schools were recruited into the sample, regardless of their class levels $(n=1.464)$. Over the period of the study from April-June 2016, those who were dropouts, excused, absent from school or did not wish to participate in the research were excluded. Nine hundred students were contacted. Eighty of these were excluded because they did not fill out the questionnaire in full; the study was ultimately completed with a total of 820 participants. This corresponded to $25 \%$ of the study universe.

\section{Instruments}

The "personal information form" and the "Pittsburgh Sleep Quality index (PSQI)" were used for the data collection.

Based on the literature the researchers developed a personal information form that contained 4 questions on demographic features, 14 questions on sleep and daily habits and 13 questions on problems with sleep, constituting a total of 31 items (1-4). The calculation of Body Mass index (BMI) on the personal information form was based on WHO body weight classifications. The BMI was calculated as weight in kilograms divided by height squared $\left(\mathrm{kg} / \mathrm{m}^{2}\right)$. In the analysis of the data and based on weight and height figures, BMI's were calculated, and using the BMI percentile curves for gender and age, the adolescents were categorized as underweight, normal or overweight. According to this assessment, those below the $5^{\text {th }}$ percentile were defined as underweight, those between the $5^{\text {th }}-85^{\text {th }}$ percentiles were designated as normal, those in the $85^{\text {th }}-95^{\text {th }}$ percentiles as overweight, while the adolescents above the $95^{\text {th }}$ percentile were defined as obese (http://apps.who. int/bmi/index.jsp?introPage=intro_3.html/) (date of access: 10.01.2018).

The PSQI was developed as a self-reporting scale in 1989 by Buysse et al. (3) to assess sleep quality and sleep disorders for use in psychiatric procedures and clinical research. The diagnostic sensitivity of PSQI to distinguish between good and poor sleep was found to be $89.6 \%$; its specificity is $86.5 \%$ (3). PSQI consists of 24 items, of which 19 are self-reported and 5 are to be answered by a spouse or roommate. The last 5 items on PSQI are not included in the assessment but only used as clinical data. The 18 items on the questionnaire are made up of 7 domains. These 7 domains are: subjective sleep quality, sleep latency, sleep duration, habitual sleep efficiency, sleep disturbances, use of sleep medication, and daytime dysfunction. Each component is assessed on the basis of 0-3. The total score for the seven domains makes up the total PSQI score.

The total PSQI score corresponds to a value between 0-21. A score of five is the cut-off point in evaluating sleep quality. A total score of over five signifies poor quality sleep; a score of five or less signifies good quality sleep (3). As the total score falls, sleep quality increases. The validity and reliability study for PSQI in Turkey was conducted by Ağargün et al. (5). Cronbach's alpha internal consistency coefficient was found to be 0.80 (5). In the present study, Cronbach's alpha internal consistency coefficient was found to be 0.81 .

The data in this study were evaluated and interpreted on the basis of the PSQI overall score.

\section{Procedure}

Once the schools where the questionnaires would be implemented were selected, the written permission of the Karabük province, Safranbolu District National Education Directorate was obtained (26.02.2016-21442463). The questionnaires were administered to the students in the presence of a guidance teacher during class hours. Prior to the distribution of the questionnaires to the students, the purpose of the study was explained to them and students filled out the forms on the basis of volunteerism. Filling out the questionnaires took approximately 20-25 minutes.

The verbal consent of the students participating in the study and of their parents was obtained.

\section{Statistical Analysis}

The data in this study were analyzed on computer. The ShapiroWilk test was employed to ascertain whether the variables showed normal distribution. In the interpretation of the results, significance was accepted as $p=0.05$. Where significance was $\mathrm{p}<0.05$, it was accepted that the variables were not normally distributed and at $\mathrm{p}>0.05$, it was considered that the variables showed normal distribution.

In examining the difference between groups, the MannWhitney $\mathrm{U}$ and Kruskal-Wallis- $\mathrm{H}$ tests were used when the variables did not display normal distribution. In the assessment, significance was accepted as 0.05 , where $p<0.05$ signified a significant difference and $\mathrm{p}>0.05$ signified the absence of a significant difference.

\section{Research Questions:}

This is a descriptive study that seeks answers to the following study questions.

1- What is the mean score of adolescents on PSQI and what is the level of their sleep quality? 
2- Do adolescents' demographic characteristics have an effect on their sleep quality?

3- Do problems with sleep have an effect on sleep quality in adolescence?

4- Do the daily habits of adolescents have an effect on the quality of their sleep?

5- Do the habits of adolescents in the one hour before going to bed affect their sleep quality?

\section{Results}

Distribution of the adolescents' demographic characteristics Of the adolescents participating in the study, 54.6\% were girls and $45.4 \%$ were boys. When class distribution was considered, it was seen that $39.5 \%$ constituted $9^{\text {th }}$ grade students, $30.2 \%$ were in the $10^{\text {th }}$ grade, $12.0 \%$ were in the $11^{\text {th }}$ grade, and $18.3 \%$ in the $12^{\text {th }}$ grade. In the calculation of the adolescents' $\mathrm{BMI}$, the finding was that $20.9 \%$ were thin, $68.0 \%$ were normal, and $11.1 \%$ were overweight. The economic status of the adolescents' parents was good in $33.4 \%$ of the families, average in $63.8 \%$ and poor in $2.8 \%$ of the families.

\section{The adolescents' PSQI distribution}

The responses the participating adolescents gave on PSQI showed that their mean overall score was $6.40 \pm 3.96$. It was found that their average duration of sleep at night was 7.24 hours. Of the adolescents, $49.6 \%$ had a good quality of sleep but the sleep quality of $50.4 \%$ was poor.

Table 1 displays a comparison of the demographic characteristics of the adolescents and their PSQI overall scores. In the overall scores, a statistically significant difference was found $(p<0.05)$ in terms of gender $(p=0.001)$ and the economic status of the family $(p=0.001)$ (Table 1$)$.

In Table 2, a comparison was made of the adolescents' sleep problems and their PSQI overall scores. Statistically significant differences $(p<0.05)$ were found in their overall scores in terms of their having difficulty falling asleep $(p=0.000)$, waking up frequently during the night $(p=0.000)$, having a hard time waking up $(p=0.000)$, having trouble breathing $(p=0.000)$, waking up startled $(p=0.000)$, seeing nightmares $(p=0.000)$ talking/murmuring in their sleep $(p=0.000)$, grinding their teeth while asleep $(p=0.000)$, feeling pain anywhere in the body $(p=0.000)$, and experiencing twitching in the legs $(p=0.000)$. No statistically significant differences $(p>0.05)$ were found in their PSQI scores in terms of sleepwalking $(p=0.052)$, snoring $(p=0.939)$ and nocturnal enuresis $(p=0.725)$ (Table 2$)$.

A comparison was made in Table 3 of the adolescents' daily habits and their PSQI scores. Statistically significant differences $(p<0.05)$ were found in their overall scores in terms of their regular use of medications $(p=0.001)$, alcohol intake $(p=0.001)$, smoking $(p=0.001)$ and the time they spent on the internet $(p=0.000)$. No statistically significant differences $(p>0.05)$ were found in their PSQI scores in terms of regular exercise $(p=0.154)$, the time they allotted to social and cultural activities $(p=0.740)$ and the time spent watching TV $(p=0.202)$ (Table 3$)$. A comparison was made in Table 4 of the adolescents' habits one hour before going to bed and their overall PSQI scores. Statistically significant differences $(p<0.05)$ were found in the overall scores in terms of surfing the internet via computer/ telephone $(p=0.000)$, watching TV $(p=0.026)$, exercising $(p=0.003)$, taking a shower $(p=0.044)$ and eating something before bed $(p=0.003)$. No statistically significant differences were found in the PSQI scores in terms of doing homework $(p=0.571)$, reading $(p=0.548)$ and drinking tea/coffee before bed $(p=0.637)(p>0.05)$ (Table 4$)$.

In Table 5, all variables were subjected to regression analysis, and those who contributed significantly to the model are shown. The regression model, which was created using variables that differ significantly in terms of PSQI in paired comparisons

\begin{tabular}{|c|c|c|c|c|c|}
\hline \multicolumn{2}{|c|}{ Demographic characteristics } & $n$ & Mean \pm SD & $z$ & $p$ \\
\hline Gender & Boys & 372 & $5.56 \pm 3.50$ & -5.224 & 0.001 \\
\hline & & \multicolumn{2}{|c|}{ PSQI } & \multicolumn{2}{|c|}{ Kruskal-Wallis $\mathrm{H}$ test } \\
\hline \multirow{3}{*}{ Class } & $10^{\text {th }}$ grade & 248 & $6.16 \pm 3.78$ & \multirow{3}{*}{5.974} & \multirow{3}{*}{0.113} \\
\hline & $11^{\text {th }}$ grade & 98 & $6.77 \pm 3.94$ & & \\
\hline & $12^{\text {th }}$ grade & 150 & $6.97 \pm 4.22$ & & \\
\hline Body Mass index & Thin & 171 & $6.59 \pm 4.30$ & 0.516 & 0.773 \\
\hline \multirow{2}{*}{$\begin{array}{l}\text { Family's economic } \\
\text { status }\end{array}$} & Average & 523 & $6.54 \pm 3.83$ & \multirow{2}{*}{15.238} & \multirow{2}{*}{0.001} \\
\hline & Poor & 23 & $9.48 \pm 5.55$ & & \\
\hline
\end{tabular}




\begin{tabular}{|c|c|c|c|c|c|}
\hline \multicolumn{2}{|l|}{ Sleep problems } & \multicolumn{2}{|c|}{ PSQI } & \multicolumn{2}{|c|}{ Mann-Whitney U test } \\
\hline & & $\mathbf{n}$ & Mean \pm SD & $\mathrm{z}$ & $p$ \\
\hline \multirow{2}{*}{ Difficulty falling asleep } & Yes & 239 & $8.75 \pm 4.20$ & \multirow{2}{*}{-10.782} & \multirow{2}{*}{0.000} \\
\hline & No & 581 & $5.43 \pm 3.42$ & & \\
\hline \multirow{2}{*}{ Waking up frequently at night } & Yes & 141 & $9.07 \pm 4.45$ & \multirow{2}{*}{-8.265} & \multirow{2}{*}{0.000} \\
\hline & No & 679 & $5.84 \pm 3.62$ & & \\
\hline \multirow{2}{*}{ Difficulty waking up } & Yes & 367 & $7.38 \pm 4.04$ & \multirow{2}{*}{-6.787} & \multirow{2}{*}{0.000} \\
\hline & No & 453 & $5.60 \pm 3.72$ & & \\
\hline \multirow{2}{*}{ Difficulty breathing } & Yes & 90 & $8.39 \pm 4.61$ & \multirow{2}{*}{-4.499} & \multirow{2}{*}{0.000} \\
\hline & No & 730 & $6.15 \pm 3.81$ & & \\
\hline \multirow{2}{*}{ Sleepwalking } & Yes & 24 & $7.75 \pm 3.81$ & \multirow{2}{*}{-1.940} & \multirow{2}{*}{0.052} \\
\hline & No & 796 & $6.35 \pm 3.96$ & & \\
\hline \multirow{2}{*}{ Waking up startled } & Yes & 143 & $9.25 \pm 4.55$ & \multirow{2}{*}{-8.588} & \multirow{2}{*}{0.000} \\
\hline & No & 677 & $5.79 \pm 3.55$ & & \\
\hline \multirow{2}{*}{ Nightmares } & Yes & 126 & $8.99 \pm 4.84$ & \multirow{2}{*}{-6.733} & \multirow{2}{*}{0.000} \\
\hline & No & 694 & $5.92 \pm 3.59$ & & \\
\hline \multirow{2}{*}{ Talking/murmuring while asleep } & Yes & 150 & $7.99 \pm 4.13$ & \multirow{2}{*}{-6.733} & \multirow{2}{*}{0.000} \\
\hline & No & 670 & $6.04 \pm 3.84$ & & \\
\hline \multirow{2}{*}{ Teeth-grinding } & Yes & 43 & $9.33 \pm 4.95$ & \multirow{2}{*}{-4.132} & \multirow{2}{*}{0.000} \\
\hline & No & 777 & $6.23 \pm 3.84$ & & \\
\hline \multirow{2}{*}{ Snoring } & Yes & 39 & $6.46 \pm 4.03$ & \multirow{2}{*}{-0.077} & 0020 \\
\hline & No & 781 & $6.39 \pm 3.96$ & & 0.939 \\
\hline Nocting & Yes & 3 & $6.00 \pm 5.29$ & 0350 & 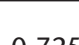 \\
\hline Nocturnal incontınence & No & 817 & $6.40 \pm 3.96$ & -0.352 & 0.125 \\
\hline Dain an & Yes & 122 & $8.38 \pm 4.15$ & $60<2$ & 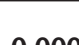 \\
\hline Pan anywnere in the pody & No & 698 & $6.05 \pm 3.83$ & -0.003 & 0.000 \\
\hline tor touitching & Yes & 72 & $9.36 \pm 4.77$ & 5700 & $00007+3$ \\
\hline Leg-tWitcning & No & 748 & $6.11 \pm 3.76$ & -3.109 & 0.000 \\
\hline
\end{tabular}

in Table 1-4, was found to be significant $(p<0.05)$. Variables that contribute significantly to the regression model explain the PSQI sleep score at a rate of $30.21 \%$. In this context, as the difficulty in falling asleep increases, the PSQI score is 2.5 times, as the state of waking up by jumping increases, PSQI score is 1.6 times, as the smoking status increases, the PSQI score is 1.6 times, as the feeling of twitching in your legs increases, the PSQI score is 1.5 times, as the rate of alcohol use increases, the PSQI score increases 1.3 times, as the gender ratio increases the PSQI score is 1.3 times, as the frequent awakening at night increases, the PSQI score increases by 1.3 times and as the rate of teeth grinding increases in sleep, the PSQI score increases 1.2 times (Table 5).

\section{Discussion}

The discussion addresses the research questions as follows: 1 - What is the mean score of adolescents on PSQI and what is the level of their sleep quality?

The mean score of the participating adolescents on PSQI was $6.40 \pm 3.96$; more than half had poor quality of sleep. Other studies conducted in Turkey report mean PSQI scores varying between 5.15-6.90, with poor sleep quality rates varying between 30.5-59\% (Dağ 2012). Studies in different countries have demonstrated mean PSQI scores of between 6.19-6.3, with poor sleep quality rates varying between $25.7-55 \%$ (6). The present study is consistent with the literature. The interaction of a variety of biological, psychological and social factors in adolescence leads the way to a shortened period of sleep. Because of the sleep deprivation that this shortened duration of sleep causes in adolescence, half of the adolescent population lives with insufficient sleep.

2- Do adolescents' demographic characteristics have an effect on their sleep quality? (Table 1)

When we considered gender in the study, it was seen that girls had poorer sleep quality. In the study by Orzech et al. (7), the authors reported that girls complained about having sleep problems more than boys while Ouyang et al. (8) said that girls slept better than boys the gender variable leads to different results depending on the study.

We found no statistically significant difference between the PSQI overall scores of the adolescents in the $9^{\text {th }}, 10^{\text {th }}, 11^{\text {th }}$ and 


\begin{tabular}{|c|c|c|c|c|c|}
\hline \multicolumn{2}{|l|}{ Daily habits } & \multicolumn{2}{|l|}{ PSQI } & \multicolumn{2}{|c|}{ Mann-Whitney U test } \\
\hline & & $\mathbf{n}$ & Mean \pm SD & z & $\mathbf{p}$ \\
\hline \multirow{2}{*}{ Regular exercise } & Yes & 228 & $6.14 \pm 4.08$ & \multirow{2}{*}{-1.427} & \multirow{2}{*}{0.154} \\
\hline & No & 592 & $6.49 \pm 3.91$ & & \\
\hline \multirow{2}{*}{ Regular use of medications } & Yes & 99 & $8.42 \pm 4.47$ & \multirow{2}{*}{-5.194} & \multirow{2}{*}{0.001} \\
\hline & No & 721 & $6.12 \pm 3.81$ & & \\
\hline \multirow{2}{*}{$\begin{array}{l}\text { Alcohol } \\
\text { intake }\end{array}$} & Yes & 65 & $8.86 \pm 5.11$ & \multirow{2}{*}{-4.179} & \multirow{2}{*}{0.001} \\
\hline & No & 755 & $6.18 \pm 3.78$ & & \\
\hline \multirow{4}{*}{ Smoking } & Yes & 129 & $8.4 \pm 4.52$ & \multirow{2}{*}{-5.837} & \multirow{2}{*}{0.001} \\
\hline & No & 691 & $6.02 \pm 3.74$ & & \\
\hline & & \multicolumn{2}{|l|}{ PSQI } & \multicolumn{2}{|c|}{ Kruskal-Wallis H test } \\
\hline & & $\mathbf{n}$ & Mean \pm SD & $\mathbf{H}$ & $p$ \\
\hline \multirow{3}{*}{$\begin{array}{l}\text { Time allotted to social and cultural } \\
\text { activities }\end{array}$} & $0-2$ hours & 482 & $6.45 \pm 3.99$ & \multirow{3}{*}{0.603} & \multirow{3}{*}{0.740} \\
\hline & $2-4$ hours & 236 & $6.22 \pm 3.81$ & & \\
\hline & 4 hours and over & 102 & $6.54 \pm 4.21$ & & \\
\hline \multirow{3}{*}{ Time spent watching TV } & $0-2$ hours & 606 & $6.54 \pm 4.09$ & \multirow{3}{*}{3.200} & \multirow{3}{*}{0.202} \\
\hline & $2-4$ hours & 159 & $5.75 \pm 3.21$ & & \\
\hline & 4 hours and over & 55 & $6.60 \pm 4.32$ & & \\
\hline \multirow{3}{*}{ Time allotted to the internet } & $0-2$ hours & 348 & $5.75 \pm 3.63$ & \multirow{3}{*}{25.373} & \multirow{3}{*}{0.000} \\
\hline & $2-4$ hours & 249 & $6.39 \pm 4.14$ & & \\
\hline & 4 hours and over & 223 & $7.41 \pm 4.07$ & & \\
\hline
\end{tabular}

\begin{tabular}{|c|c|c|c|c|c|}
\hline \multicolumn{2}{|l|}{ Habits one hour before going to bed } & \multicolumn{2}{|c|}{ PSQI } & \multicolumn{2}{|c|}{ Mann-Whitney U test } \\
\hline & & \multirow{2}{*}{$\begin{array}{l}\mathbf{n} \\
177 \\
\end{array}$} & \multirow{2}{*}{$\begin{array}{l}\text { Mean } \pm \text { SD } \\
6.44 \pm 3.73\end{array}$} & \multirow{3}{*}{$\begin{array}{l}z \\
-0.566\end{array}$} & \multirow{3}{*}{$\begin{array}{l}\mathbf{p} \\
0.571\end{array}$} \\
\hline \multirow{2}{*}{ Doing homework } & Yes & & & & \\
\hline & No & 643 & $6.38 \pm 4.03$ & & \\
\hline \multirow{2}{*}{ Reading } & Yes & 152 & $6.64 \pm 4.27$ & \multirow{2}{*}{-0.601} & \multirow{2}{*}{0.548} \\
\hline & No & 668 & $6.34 \pm 3.89$ & & \\
\hline \multirow{2}{*}{ Surfing on the computer/telephone } & Yes & 532 & $6.77 \pm 3.98$ & \multirow{2}{*}{-4.181} & \multirow{2}{*}{0.000} \\
\hline & No & 288 & $5.69 \pm 3.84$ & & \\
\hline \multirow{2}{*}{ Watching TV } & Yes & 256 & $5.89 \pm 3.66$ & \multirow{2}{*}{-2.222} & \multirow{2}{*}{0.026} \\
\hline & No & 564 & $6.62 \pm 4.08$ & & \\
\hline \multirow{2}{*}{ Exercising } & Yes & 46 & $4.70 \pm 3.81$ & \multirow{2}{*}{-3.667} & \multirow{2}{*}{0.000} \\
\hline & No & 774 & $6.50 \pm 3.95$ & & \\
\hline \multirow{2}{*}{ Taking a shower } & Yes & 184 & $7.13 \pm 4.62$ & \multirow{2}{*}{-2.017} & \multirow{2}{*}{0.044} \\
\hline & No & 636 & $6.18 \pm 3.73$ & & \\
\hline Drinking tea/coffee & Yes & 149 & $6.34 \pm 3.53$ & \multirow{2}{*}{-0.472} & \multirow{2}{*}{0.637} \\
\hline Before going to bed & No & 671 & $6.41 \pm 4.05$ & & \\
\hline Eating something & Yes & 125 & $7.20 \pm 3.81$ & \multirow{2}{*}{-2.983} & \multirow{2}{*}{0.003} \\
\hline Before going to bed & No & 695 & $6.25 \pm 3.98$ & & \\
\hline
\end{tabular}

$12^{\text {th }}$ grades. On the other hand, we observed that $12^{\text {th }}$ grade students had higher PSQI overall scores compared to the other classes, meaning that the quality of their sleep was the poorest $(6.97 \pm 4.22)$. Researchers of other studies have shown that sleep duration becomes shorter and grows poorer toward the end of the adolescent years (7). The reason for the decline in the quality of sleep at this time may be due to the fact that this period corresponds to the time when adolescents prepare for 


\begin{tabular}{|l|l|l|l|}
\hline \multicolumn{4}{|l|}{ Table 5. Regression model } \\
\hline Regression model & B & t & p \\
\hline & 2.501 & 9.414 & 0.000 \\
\hline Difficulty falling asleep (yes/no) & 1.690 & 5.149 & 0.000 \\
\hline Waking up startled (yes/no) & 1.661 & 4.487 & 0.000 \\
\hline Smoking (yes/no) & 1.525 & 3.620 & 0.000 \\
\hline Leg-twitching (yes/no) & 1.389 & 2.771 & 0.006 \\
\hline Alcohol intake (yes/no) & 1.369 & 5.649 & 0.000 \\
\hline Gender (F/M) & 1.317 & 3.970 & 0.000 \\
\hline Waking up frequently at night (yes/no) & 1.208 & 2.262 & 0.024 \\
\hline Teeth-grinding (yes/no) & & & \\
\hline
\end{tabular}

university entrance exams in the various countries. They are challenged by their increased workload during this period and by the stress of having to meet their family's expectations.

It was seen in the study that the sleep quality of adolescents is not affected by their BMI. Other studies however have shown that obesity does have an impact on the duration of sleep (9). In the present study, our classification of BMI was made as thin, normal and overweight; we did not assign a classification for obesity. It may be that the reason we did not find a significant difference in sleep quality in terms of BMI was because the adolescents in the study were mostly of normal weight (68\%). It was seen in the study that the more disadvantaged the adolescents' parents were in terms of their economic status, the poorer was the adolescent's sleep quality. Researchers have reported that socio-economic factors such as poverty, race, employment status are correlated with poor sleep quality and it is seen that these factors have an adverse impact on the sleep quality of adolescents as well $(3,9)$. A worsening of economic conditions has been found to lead to a turbulent family environment and to physical conditions that make it difficult to sleep restfully. We think therefore that disadvantaged socioeconomic conditions also contribute to the decline in sleep quality in adolescence.

3- Do problems with sleep have an effect on sleep quality in adolescence? (Table 2)

It was found in the study that problems with sleep such as having difficulty falling asleep, waking up frequently during the night, having trouble waking up, having difficulty breathing, jumping up abruptly from sleep, nightmares, talking/mumbling in sleep, teeth-grinding, experiencing pain anywhere in the body and leg twitching had a negative effect on the sleep quality of adolescents. In a study by Chung and Cheung (10), it was shown that the most common problems with sleep were having trouble waking up early in the morning, waking up frequently during the night and having difficulty falling asleep. Sweileh et al. (11) reported the most common sleep problems as talking in one's sleep, sleepwalking, bruxism, nightmares and Restless Leg syndrome. In our study, we found no significant difference in PSQI scores in terms of sleepwalking, snoring and nocturnal incontinence. We believe that the lack of a difference may have stemmed from the fact that there were very few individuals in our sample who had these problems. It may be considered also that differences in problems with sleep may derive from cultural influences.

4- Do the daily habits of adolescents have an effect on the quality of their sleep? (Table 3)

Those in the study who smoked had a poorer quality of sleep than those who did not smoke. It has been reported in previous studies that smoking is correlated with longer periods of sleep latency and with sleeping shorter and lighter phases of sleep (12). Smoking is accepted as a type of behavior that is a barrier to sleep. The toxins contained in cigarettes accumulate in the body and have the potential of preventing restful sleep. In particular, the reason that smoking before bedtime makes it more difficult to fall asleep is the stimulating effect of the nicotine contained in cigarettes. It is also believed that the number of cigarettes smoked has an effect in this context.

The adolescents who consumed alcoholic drinks had a poorer quality of sleep. Studies have shown that alcohol consumption causes a delay in getting to bed as well as excessive sleep, which are factors that have an adverse effect on the quality of sleep (13). The consumption of alcohol brings down the body temperature, leading to a deep sleep, thus disrupting the cycle of sleep and interrupting the phase of sleep in which rest takes place. Because alcohol consumption usually occurs in the evening, this is the reason sleep is delayed. The curiosity and encouraging atmosphere that make smoking and drinking attractive to adolescents do not only present a risk to their health but also lead to low quality sleep.

It was found in the study that the time the adolescents allotted to using the internet affected the quality of their sleep, but that social and cultural activities and spending time watching TV did not. We asked the adolescents how many hours they used their technological devices and found that those who spent 4 hours or more especially on the internet had a poor quality of sleep compared to the others. Other studies have determined that spending 2 hours or more on watching TV or on the computer, surfing the internet, is correlated with difficulty in falling asleep and waking up (14). In particular, a strong correlation has been found between short durations of sleep and the use of electronic devices at night (1). In one study, however, the researchers could not find a statistically significant relationship between sleep quality scores and time spent watching TV or using the computer (15). In many studies conducted with adolescents, it has been demonstrated that exposure to electronic devices in the evening hours has the potential of disrupting sleep patterns. The simultaneous use of more than one electronic device is known to be correlated to sleeping less at night and being sleepy during the daytime. Today's technology has driven individuals to a life with telephones and tablets, leading to a reduced rate of TV viewing, and the transfer of social and cultural activities to the environment of the social media. This has increased the use of the internet, causing delays in falling asleep time and shortening sleep durations.

5- Do the habits of adolescents in the one hour before going to bed affect their sleep quality? (Table 4)

When we examined the adolescents' activities before they went to bed, we found that those who spent time on their 
computers/telephones surfing the internet had poorer sleep quality. It was seen that individuals who watched TV before bedtime had better sleep quality. Previous researchers have reported in their studies that children and adolescents watching TV or spending time on their computers or cell phones, surfing the internet or playing games are more likely to suffer from sleep deprivation and consequently are sleepy during the day (14). It is observed that adolescents who have difficulty waking up early for school have spent their time before bed on their computers or telephones and delayed their bedtimes. Because of this, the duration of their sleep time diminishes and the quality of their sleep suffers.

It was seen in the study that there was no difference in the quality of sleep of those adolescents who engaged in regular exercise before bed and that exercise performed just before bed even had a positive impact on the quality of sleep. A review of previous studies shows that adolescents who are in the habit of exercising and engaging in sports have better sleep quality (4). On the other hand, there are also studies in which a high rate of poor sleep has been reported for individuals who exercise. Epidemiological studies point to the positive effects of exercise on sleep. The individuals participating in these studies have reported that exercising helps them to fall asleep easier and affords them deeper sleep at night. Including exercise in sleep preparation rituals facilitates sleep hygiene and relaxation. Exercises suitable to an individual's physical environment that are performed before bedtime and which are aimed at winding down and relaxing rather than engaging in heavy physical activity are believed to have a positive effect on sleep. In general, exercise is accepted as beneficial to sleep and the differences registered in various studies is perhaps a result of multiple factors such as differences in the gender, age, state of fitness of the individuals concerned or the specifics of the exercise performed (concentration, duration, the time of day, the environment).

The adolescents in the study suffered poor sleep quality when they ate something before going to bed. It has been reported that nighttime eating disrupts circadian rhythms and that irregular sleep patterns such as going to bed late and waking up late stimulates the tendency toward nighttime food consumption (16). Eating right before bedtime disrupts the individual's metabolism and makes it harder to fall asleep. The quality of sleep also declines when there are changes made in the times and amounts food is consumed.

The study revealed that pre-bedtime activities such as doing homework and reading did not affect the adolescents' sleep. There is a study however that has demonstrated that the most common barrier to a good night's sleep among adolescents is having to tackle too much homework (17). Another study has asked adolescents the question, "Do you have any habits before bedtime that cause you to fall asleep easily?" of the respondents, 20\% replied, "reading" (18). Bedtime rituals differ between individuals and between cultures. It may be useful to make a more detailed investigation into these varied activities. Our study showed that the adolescents' sleep was not affected by drinking coffee or tea before bed. It has been shown in other studies that a high consumption of caffeine shortens sleep durations, delays the start of sleep, increases the number of times an individual awakes during the night, and causes sleepiness during the day (14). Researchers report in one study that tea or coffee consumption does not affect mean PSQI overall scores (19). The literature in general however points to tea, coffee and other drinks containing caffeine as factors that make it harder to fall asleep, cause interruptions in sleep, all of which take their toll on the quality of sleep. The differences may be explained by the amounts of tea/coffee consumed and by intercultural differences as well.

\section{Study Limitations}

Because this study was only conducted in the district of Safranbolu in Karabük, Turkey, the responses of the adolescents are limited to the answers to the PSQI questionnaire given by the students in the specified high schools at the time the study was carried out. There are also cognitive limitations that may have arisen from a faulty interpretation of the questions on the part of the respondents.

\section{Conclusion}

Problems with sleep can cause deterioration in the quality of sleep during adolescence. At the same time, the disadvantaged economic status of a family, smoking and alcohol intake, various bedtime rituals and especially excessive use of computers, cell phones and internet are factors that have an adverse effect on quality of sleep. Physiological and psychological changes that affect sleep have shown similarities over history but today's sociocultural, technological and lifestyle trends are closely correlated with disruptions of sleep patterns.

\section{Implications for school health}

- It is recommended that more studies be carried out to explore lifestyle factors that are related to poor sleep quality and that school nurses determine the reasons for underlying problems.

- It is important that school nurses identify and follow-up on sleep problems adolescents may have and reduce these to a minimum.

- In order to attain an improvement in their quality of sleep, adolescents should be encouraged to replace pre-bedtime activities such as eating right before bed, surfing the internet, taking in caffeine and smoking by activities that facilitate sleep such as taking a warm shower, reading and doing relaxation exercises.

- It is important that they refrain from engaging in heavy physical activity 3-4 hours before going to bed. Adolescents should be taught calming relaxation and breathing exercises that they can perform right before bed.

The time young people today spend watching TV, surfing the internet and using their cell phones has reached a dimension that actually negatively impacts many of their health behaviors in the domains of good nutrition, social relations and sleep. In the context of sleep, adolescents and their families need to be educated on using and putting limits on technology so that sleep integrity can be achieved. School health services have an important responsibility in this context. Parents should set 
down suitable bedtimes and be helped in learning how to enforce these rules.

\section{Acknowledgments}

I am grateful to Assistant Professor Dr. Gülcan Kar Şen for her valuable guidance and contributions to the planning, conducting and concluding of my study.

\section{Ethics}

Ethics Committee Approval: The approval of the Karabük University Ethics Committee was obtained prior to the study (January 26, 2016-decision no: 18- 2016/02). The written permission of the Karabük province, Safranbolu District National Education Directorate was obtained (26.02.2016-21442463).

Informed Consent: The verbal consent of the students participating in the study and of their parents was obtained.

Peer-review: Internally peer-reviewed.

\section{Authorship Contributions}

Concept: N.G.T., G.K.Ş., Design: N.G.T., G.K.Ş., Data Collection or Processing: N.G.T., G.K.Ş., Analysis or Interpretation: N.G.T., G.K.Ş., Literature Search: N.G.T., G.K.Ş., Writing: N.G.T., G.K.Ş. Conflict of Interest: No conflict of interest was declared by the authors.

Financial Disclosure: The authors declared that this study received no financial support.

\section{References}

1. Owens J, Adolescent Sleep Working Group. Insufficient sleep in adolescents and young adults: an update on causes and consequences. Pediatrics. 2014;134:e921-32. doi: 10.1542/peds.2014-1696.

2. Felden EPG, Leite CR, Rebelatto CF, Andrade RD, Beltrame TS. [Sleep in adolescents of different socioeconomic status: a systematic review.] Rev Paul Pediatr 2015;33:467-73.

3. Buysse DJ, Reynolds C, Monk T, Berman SR, Kupfer DJ. The pittsburgh sleep quality index: a new instrument for psychiatric practice and research. Psychiatry Res 1989;28:193-213.

4. Bülbül S, Kurt G, Ünlü E, Kırlı E. Sleep problems in adolescence and the effective factors. Çocuk Sağlığı ve Hastalıkları Dergisi 2010;53:204-10.

5. Ağargün MY, Kara $H$, Anlar Ö. The validity and reliability of the pittsburgh sleep quality Index. Türk Psikiyatri Dergisi 1996;7:107-15.
6. Buysse DJ, Hall ML, Strollo PJ, Kamarck, TW, Owens J, Lee L, Matthews KA. Relationships between the Pittsburgh Sleep Quality Index (PSQI), Epworth Sleepiness Scale (ESS), and clinical/polysomnographic measures in a community sample. J Clin Sleep Med 2008;4:563-71.

7. Orzech KM, Salafsky DB, Hamilton LA. The state of sleep among college students at a large public university. I Am Coll Health 2011;59:612-9.

8. Ouyang F, Lu BS, Wang B, Yang J, Li Z, Wang L, Zee PC. Sleep patterns among rural Chinese twin adolescents. Sleep Med 2009;10:479-89.

9. Moore M, Kirchner HL, Drotar D, Johnson N, Rosen C, Redline S. Correlates of adolescent sleep time and variability in sleep time: the role of individual and health related characteristics. Sleep Med 2011; 12:239-45.

10. Chung KF, Cheung MM. Sleep-wake patterns and sleep disturbance among Hong Kong Chinese adolescents. Sleep 2008;31:185-94.

11. Sweileh WM, Ali IA, Sawalha AF, Abu-Taha AS, Sa'ed HZ, Al-Jabi SW. Sleep habits and sleep problems among Palestinian students. Child Adolesc Psychiatry Ment Health 2011;5:25.

12. Zhang L, Samet J, Caffo B, Punjabi NM. Cigarette smoking and nocturnal sleep architecture. Am J Epidemiol 2006;164:529-37.

13. Singleton RA, Wolfson AR. Alcohol consumption, sleep, and academic performance among college students. I Stud Alcohol Drugs 2009;70:355-63.

14. Bartel KA, Gradisar M, Williamson P. Protective and risk factors for adolescent sleep: a meta-analytic review. Sleep Med Rev 2015;21:72-85.

15. Erdoğan N, Karabel MP, Tok Ş, Bedir N, Köse E, Inci BM, Ekerbiçer HÇ. Sakarya Üniversitesi Tıp Fakültesi öğrencilerinde uyku kalitesi ve etkileyen faktörler. In 19. Ulusal Halk Sağlığı Kongresi. 2017:396-402. (Erişim Tarihi: 20.5.2018)

16. Orhan FÖ, Tuncel D. Night eating disorders. Curr Approaches Psychiatry 2009;1:132-54.

17. Noland H, Price JH, Dake J, Telljohann SK. Adolescents' sleep behaviors and perceptions of sleep. J Sch Health 2009;79:224-30.

18. Mayda AS, Kasap H, Yıldırım C, Yılmaz M, Derdiyok Ç, Ertan D, Karakaya $\mathrm{H}$. Prevalence of sleep disorders in 4-5-6. class students of medical faculty. Düzce Üniversitesi Sağlık Bilimleri Enstitüsü Dergisi 2012;2:8-11.

19. Üstün Y, Yücel ŞÇ. Hemşirelerin uyku kalitesinin incelenmesi. Maltepe Üniversitesi Hemşirelik Bilim ve Sanatı Dergisi 2011;4:29-38. 